\title{
BK viremia in critically ill surgical patients with hemorrhagic or septic shock
}

\author{
Maximilian Nass ${ }^{1}$, Benedikt Weissbrich², Moritz Huber ${ }^{1}$, Elisabeth Marion Schneider ${ }^{3}$ and Manfred Weiss ${ }^{1 *}$
}

\begin{abstract}
Background: Infections with polyomavirus BK virus (BKV) are a common cause of renal dysfunction after renal transplantation and may also be harmful in surgical patients with shock. The aim of the present study was to determine the frequency of BKV viremia in critically ill surgical patients with septic or hemorrhagic shock, and, if viremia is detectable, whether viremia may be associated with renal dysfunction.

Findings: A total of 125 plasma samples from 44 critically ill surgical patients with septic or hemorrhagic shock were tested by real-time polymerase chain reaction (PCR) for BKV DNA during their stay on the intensive care unit (ICU). BKV viremia occurred in four patients, i.e. in three of the septic and in one of the hemorrhagic shock group. There was no association between viremia and renal dysfunction. All positive samples contained a low viral load (<500 copies/ml).

Conclusions: Since BK viremia was rarely found and with low viral load only in critically ill surgical patients with shock, it is very unlikely that BK viremia results in BK nephropathy later on.
\end{abstract}

Keywords: Acute kidney injury, Critically ill, Polyomavirus, BK virus, Sepsis, Shock

\section{Background}

Infections with BK virus (BKV) are an increasing problem and a common cause of renal dysfunction after allograft renal transplantation [1,2]. IgG seroprevalence for BK virus (BKV) was $82 \%$ in healthy blood donors, and, over a period of 14 months, no BKV viruria was detectable [3]. Kaneko and colleagues reported prevalence of BKV in urine samples in about $13.5 \%$ of the healthy control group, $33.3 \%$ of patients with chronic renal disease, and $55.6 \%$ of patients with renal disease under cortisone therapy [4].

Critically ill nonimmunosuppressed patients with either trauma or sepsis have been reported to demonstrate immunologic features consistent with immunosuppression ("immunoparalysis"), i.e. cytomegalovirus or herpes simplex virus reactivation or infections [5-8]. Thus, we hypothesized that BKV viremia might also occur in critically ill surgical patients. Since the appearance of a BKV nephropathy was strongly associated with the viral load detected in renal transplant patient's

\footnotetext{
* Correspondence: manfred.weiss@uni-ulm.de

'Department of Anaesthesiology, University Hospital UIm, Steinhoevelstr. 9, 89075 Ulm, Germany

Full list of author information is available at the end of the article
}

blood [1], we focused on detection of viral load in the blood of surgical critically ill patients. The aim of the present study was to determine the frequency of BKV viremia in surgical critically ill patients with hemorrhagic or septic shock.

\section{Methods}

\section{Patients and data collection}

The prospective study is in compliance with the Helsinki declaration and was approved by the Independent Ethics Committee of the University Ulm (65/07). All surgical patients admitted to the Anaesthesiology adult ICU between August 2008 and December 2008 with severe SIRS/sepsis, septic or haemorrhagic shock on admission or developing septic or haemorrhagic shock on the ICU were included in the present study, in total, 51 cases $\geq 18$ years with shock. Four patients of the hypovolaemic shock group and three patients of the septic shock group had to be excluded from further analysis, due to refusal of informed consent, stay $<24$ hours on ICU, early demission to another ICU or concomitant cardiogenic shock. Thus, in total, blood samples of 44 critically ill shock patients were included for analysis of BKV deoxyribonucleic acid (DNA), 18 in the septic 
shock group and 26 in the hemorrhagic shock group (http://ClinicalTrials.gov ID: NCT00736827). Blood samples were taken before, during and after shock: on the first days of severe SIRS/sepsis; shock with a noradrenaline dose in $\mu \mathrm{g} / \mathrm{kg} \times \mathrm{min}$ of $>0$ and $\leq 0.1>2 \mathrm{~h},>0.1$ and $\leq 1.0>2 \mathrm{~h},>1.0>2 \mathrm{~h}$, or $>1.0+$ adrenaline $>2 \mathrm{~h}$; after septic shock; before demission from the ICU or before death.

\section{Diagnosis of sepsis, acute kidney injury (AKI) and severity of organ dysfunctions and of disease}

Sepsis and septic shock were defined using the 2003 SCCM/ESICM/ACCP/ATS/SIS sepsis definitions [9]. Shock was defined as hypotension despite adequate volume resuscitation, a systolic blood pressure of $\leq 90$ $\mathrm{mmHg}$, or the need of vasopressors to keep blood pressure $\geq 90 \mathrm{mmHg}$.

Acute kidney injury (AKI) was defined by the Acute Kidney Injury Network criteria [10], which are based on acute alterations in serum creatinine or urine output. Severity of organ dysfunctions was evaluated daily by the SOFA score (Sequential Organ Failure Assessment) [11], and of sepsis by the 2003 sepsis definitions [9].

Severity of disease on admission was monitored by the SAPS 3 score (Simplified Acute Physiology Score 3) [12] and the APACHE II score (Acute Physiology and Chronic Health Evaluation II) [13].

\section{Blood samples}

Blood samples were taken from arterial lines of the patients at the ICU. Samples were immediately centrifuged and plasma was stored at $-20^{\circ} \mathrm{C}$ until testing.

\section{Detection of BKV DNA by real-time PCR}

The presence of BKV DNA was tested via real-time polymerase chain reaction (PCR) [14]. DNA was extracted from $200 \mu \mathrm{l}$ of the plasma samples using the High Pure viral nucleic acid kit (Roche, Mannheim, Germany) according to the instructions of the manufacturer. The efficiency of the nucleic acid purification was controlled by co-extraction and subsequent amplification of Herpes virus saimiri DNA. The BKV real-time PCR was performed in a final volume of $20 \mu \mathrm{l}$ consisting of $5 \mu \mathrm{l}$ of DNA, primers, probe at a final concentration of $200 \mathrm{nM}$ each, and $1 \times$ Quantitect probe master mix (QIAGEN, Hilden, Germany). For real-time BK PCR, primer 1 with sequence (5'-3')AGCAGGCAAGGGTTCTATTACTAAAT, primer 2 with GAAGCAACAGCAGATTCTCAACA, and probe with AAGACCCTAAAGACTTTCC CTCTGATCTACACCAGTTT were used [14]. Amplification was performed on a 7500 real-time PCR system (Applied Biosystems, Darmstadt, Germany). The cycling conditions were 50 cycles with $30 \mathrm{~s}$ at $95^{\circ} \mathrm{C}$ and $60 \mathrm{~s}$ at $60^{\circ} \mathrm{C}$ after a preheating step of $15 \mathrm{~min}$ at $95^{\circ} \mathrm{C}$. The lower limit of quantification was 300 copies/ml. General laboratory procedures to prevent PCR contamination were strictly adhered to. One negative probe was extracted and amplified for every five samples.

\section{Statistical analyses}

Rates of BKV DNA detection in blood of consecutive patients are given. No statistical analyses were performed.

\section{Results}

The study included 44 patients, 18 in septic shock and 26 in hemorrhagic shock.

Patient's characteristics and scores are summarized in Table 1. Median total stay in the ICU was 9 days (range 2-52) and in the hospital 30 days (range 3-117), respectively. Twenty-two patients had no acute kidney injury (AKI), and 22 AKI stages 1 to 3. 9/44 patients required renal replacement therapy (RRT).

At least two, and up to five blood samples were collected per patient. A total of 125 plasma samples was analyzed for BKV DNA. Results regarding viral load before, during and after shock are given in Table 2. In total, five blood samples of four patients were tested positive for BKV DNA. The viral load in all positive samples was low $\left(\leq 4.4 \times 10^{2}\right.$ copies $\left./ \mathrm{ml}\right)$. One septic shock patient, only, revealed AKI stage 2 at maximum and BKV viremia. None of the four BKV positive patients needed RRT (Tables 1 and 2). None of the nine patients with RRT was tested positive for BKV viral DNA.

\section{Discussion}

The main result of the present study is that BKV viremia was rarely found in critically ill surgical patients with shock and with low viral load, only.

Due to the small sample size, conclusions have to be drawn with caution. We focused on BKV viremia, since BKV nephropathy with renal failure has been reported to be strongly associated with viral load in patient's blood [1]. All patients with a low viral load $\left(<1.9 \times 10^{5}\right.$ copies $\left./ \mathrm{ml}\right)$ had a stable renal function without treatment [1]. Thus, our results with low viral load $\left(\leq 4.4 \times 10^{2}\right.$ copies $\left./ \mathrm{ml}\right)$ and only one BK positive patient revealing AKI stage 2 , are in agreement with these data [1].

In immunosuppressed patients, onset of viruria and viremia occurred 40.5 days (range: 0-415 days) and 60 days (range: 18-276 days) post renal transplantation [15]. Median onset of BKV replication in urine by detecting decoy cells was estimated at 16 weeks (range: 2-69 weeks), of viral DNA in blood at 23 weeks (range: 4-73 weeks), and of BK polyoma virus associated nephropathy (PyVAN) at 28 weeks (range: 8-86 weeks) following renal transplantation [16]. Thus, only patient 5 (Table 2) was in the range, BKV nephropathy might 
Table 1 Patient characteristics and scores

\begin{tabular}{|c|c|c|c|c|c|c|c|c|c|c|}
\hline & & Total & Shock & & RRT & & $\begin{array}{l}\text { Maxim } \\
\text { stage }\end{array}$ & I acute & dney in & \\
\hline & & & $\begin{array}{l}\text { Hemor- } \\
\text { rhagic }\end{array}$ & Septic & Yes & No & $\begin{array}{l}\text { Stage } \\
0\end{array}$ & $\begin{array}{l}\text { Stage } \\
1\end{array}$ & $\begin{array}{l}\text { Stage } \\
2\end{array}$ & $\begin{array}{l}\text { Stage } \\
3\end{array}$ \\
\hline Patients & $n=$ & 44 & 26 & 18 & 9 & 35 & 22 & 13 & 6 & 3 \\
\hline \multirow[t]{2}{*}{ Age, years } & $\begin{array}{l}\text { Median } \\
\text { Range }\end{array}$ & 56.5 & 52.5 & 60 & 69 & 53 & 54.5 & 51 & 68.5 & 63 \\
\hline & & $\begin{array}{l}20- \\
88\end{array}$ & $20-81$ & $37-88$ & $\begin{array}{l}45- \\
73\end{array}$ & $\begin{array}{l}20- \\
88\end{array}$ & $21-88$ & $20-81$ & $60-71$ & $45-70$ \\
\hline Male/female & $n=$ & $35 / 9$ & $19 / 7$ & $16 / 2$ & $8 / 1$ & $27 / 8$ & $16 / 6$ & $11 / 2$ & $5 / 1$ & $3 / 0$ \\
\hline \multirow[t]{2}{*}{ Stay in hospital before ICU, days } & Median & 1 & 1 & 4 & 3 & 1 & 1 & 0 & 5 & 2 \\
\hline & Range & $0-36$ & $0-14$ & $0-36$ & $0-15$ & $0-36$ & $0-36$ & $0-19$ & $2-15$ & $2-5$ \\
\hline \multirow[t]{2}{*}{ Days on ICU } & Median & 9 & 8 & 12 & 17 & 7 & 6 & 15 & 17 & 25 \\
\hline & Range & $2-52$ & $3-52$ & $2-34$ & $3-43$ & $2-52$ & $2-24$ & $3-28$ & $7-52$ & $5-34$ \\
\hline \multirow[t]{2}{*}{ Stay in hospital after ICU } & Median & 12 & 9 & 17 & 5 & 15 & 12 & 11 & 17 & 11 \\
\hline & Range & $\begin{array}{l}0- \\
111\end{array}$ & $0-48$ & $0-111$ & $0-41$ & $\begin{array}{l}0- \\
111\end{array}$ & $0-111$ & $0-46$ & $0-41$ & $11-25$ \\
\hline \multirow[t]{2}{*}{ Days in hospital } & Median & 30 & 24.5 & 44 & 24 & 31 & 24 & 29 & 54 & 50 \\
\hline & Range & $\begin{array}{l}3- \\
117 \\
\end{array}$ & $3-73$ & $3-117$ & $3-73$ & $\begin{array}{l}5- \\
117 \\
\end{array}$ & $3-117$ & $3-65$ & $20-73$ & $18-52$ \\
\hline \multirow{2}{*}{$\begin{array}{l}\text { Period under BKV observation, days before }+ \text { on } \\
\text { ICU }\end{array}$} & Median & 14 & 10 & 19.5 & 20 & 13 & 7.5 & 16 & 26.5 & 27 \\
\hline & Range & $3-57$ & $3-57$ & $3-43$ & $3-57$ & $3-54$ & $3-43$ & $3-35$ & $9-57$ & $7-39$ \\
\hline \multirow[t]{2}{*}{ SOFA score } & Median & 9 & 8 & 9 & 13 & 8 & 7.5 & 9 & 9.5 & 12 \\
\hline & Range & $3-18$ & $3-15$ & $5-18$ & $9-18$ & $3-12$ & $4-12$ & $3-18$ & $7-15$ & $10-16$ \\
\hline \multirow[t]{2}{*}{ SAPS3 score } & Median & 45 & 47 & 42.5 & 66 & 45 & 45 & 45 & 56.5 & 45 \\
\hline & Range & $\begin{array}{l}24- \\
87\end{array}$ & $26-87$ & $24-87$ & $\begin{array}{l}26- \\
87\end{array}$ & $\begin{array}{l}24- \\
71\end{array}$ & $33-71$ & $24-87$ & $39-87$ & $26-68$ \\
\hline \multirow[t]{2}{*}{$\overline{\text { APACHE } \| \text { score }}$} & Median & 20 & 22.5 & 18 & 30 & 20 & 21 & 18 & 24.5 & 18 \\
\hline & Range & $\begin{array}{l}10- \\
45\end{array}$ & $10-45$ & $11-37$ & $\begin{array}{l}16- \\
45\end{array}$ & $\begin{array}{l}10- \\
36\end{array}$ & $11-30$ & $10-37$ & $15-45$ & $16-33$ \\
\hline ICU survival/death & & $39 / 5$ & $24 / 2$ & $15 / 3$ & $6 / 3$ & $33 / 2$ & $21 / 1$ & $10 / 3$ & $5 / 1$ & $3 / 0$ \\
\hline RRT/no RRT & & $9 / 35$ & $3 / 23$ & $6 / 12$ & I & I & $1 / 21$ & $3 / 10$ & $3 / 3$ & $2 / 1$ \\
\hline \multirow[t]{2}{*}{ Total days with AKI } & Median & 1 & 0 & 1 & 7 & 0 & 0 & 1 & 8 & 20 \\
\hline & Range & $0-26$ & $0-13$ & $0-26$ & $0-26$ & $0-8$ & 0 & $1-9$ & $2-13$ & $4-26$ \\
\hline AKI on demission from hospital & $n=$ & 13 & 4 & 9 & 5 & 8 & 2 & 7 & 3 & 1 \\
\hline BKV reactivation & $n=$ & 4 & 1 & 3 & 0 & 4 & 3 & 0 & 1 & 0 \\
\hline
\end{tabular}

AKI acute kidney injury; RRT renal replacement therapy; SOFA highest value during ICU stay; SAPS3 and APACHE II: value on admission to ICU

have been detected, underlying the reported range of 56 up to 602 days [16]. Thus, our observation period may have been too short to detect BK nephropathy.

In the present study, diagnosis of AKI was based on current clinical definitions [10], which do not reflect the underlying pathogenetic mechanisms of BK-PyVAN, diagnosed by renal biopsy and histologically on tubularinterstitial nephropathy [17].

In renal transplant recipients, a high BK viral load in plasma (> 10000 copies/ml) for more than three weeks suggests that BK-PyVAN is highly likely, i.e. "presumptive BK-PyVAN" [18]. In our four patients with BK viremia, viral load was low and did not exceed three weeks, making
BK-PyVAN very unlikely. Decoy cells and viral DNA in urine are used for screening purposes and response to therapeutic interventions for BK-PyVAN. Due to low viral load in blood in our patients, these screening methods might have detected more cases of BK reactivation, however, with even minor relevance for the clinician since large nucleus decoy cells do not necessarily point to the development of BK-PyVAN.

Studies in non-renal solid organ transplant recipients have shown variable prevalence of BK viruria and scarcely $\mathrm{BK}$ viremia during the first post-transplant year and in allograft recipients with deteriorating renal function, and presence of BKV in urine or blood was not associated with 


\section{Table 2 BKV reactivation in patients with hemorrhagic or septic shock}

\begin{tabular}{|c|c|c|c|c|c|c|c|c|c|c|c|c|c|c|c|}
\hline \multirow[t]{2}{*}{$\begin{array}{l}\text { Pat. } \\
\text { no. }\end{array}$} & \multirow[t]{2}{*}{$\begin{array}{l}\text { Shock } \\
\text { group }\end{array}$} & \multirow{2}{*}{$\begin{array}{l}\text { Days in } \\
\text { hospital } \\
\text { before ICU }\end{array}$} & \multirow[t]{2}{*}{$\begin{array}{l}\text { Days } \\
\text { on } \\
\text { ICU }\end{array}$} & \multirow[t]{2}{*}{$\begin{array}{l}\text { Days in } \\
\text { hospital after } \\
\text { ICU }\end{array}$} & \multirow[t]{2}{*}{$\begin{array}{l}\text { Total days } \\
\text { in hospital }\end{array}$} & \multirow[t]{2}{*}{$\begin{array}{l}\text { Day at ICU with } \\
\text { BKV detection }\end{array}$} & \multicolumn{4}{|c|}{$\begin{array}{l}\text { Viral load } \\
\text { (copies/ml) }\end{array}$} & \multirow[t]{2}{*}{ Survival } & \multirow[t]{2}{*}{$\begin{array}{l}\text { AKI } 1 \\
\text { days }\end{array}$} & \multirow[t]{2}{*}{$\begin{array}{l}\text { AKI } 2 \\
\text { days }\end{array}$} & \multirow[t]{2}{*}{$\begin{array}{l}\text { AKI } 3 \\
\text { days }\end{array}$} & \multirow[t]{2}{*}{$\begin{array}{l}\text { AKI stage } \\
\text { on } \\
\text { demission }\end{array}$} \\
\hline & & & & & & & $\begin{array}{l}\text { 1st day } \\
\text { severe SIRS/ } \\
\text { sepsis }\end{array}$ & $\begin{array}{l}\text { 1st } \\
\text { day } \\
\text { shock }\end{array}$ & $\begin{array}{l}\text { 1st day } \\
\text { after shock }\end{array}$ & $\begin{array}{l}\text { before } \\
\text { demission/ } \\
\text { death }\end{array}$ & & & & & \\
\hline 37 & hemorrhagic & 0 & 11 & 4 & 15 & 4 & & & $<300^{*}$ & & + & 0 & 0 & 0 & 0 \\
\hline 5 & septic & 0 & 6 & 111 & 117 & 2 & 440 & & & & + & 0 & 0 & 0 & 0 \\
\hline 19 & septic & 2 & 4 & 0 & 6 & 2 and 4 & & $<300$ & & $<300$ & - & 0 & 0 & 0 & 0 \\
\hline 29 & septic & 6 & 15 & 25 & 46 & 3 & & & $<300$ & & + & 6 & 2 & 0 & 2 \\
\hline
\end{tabular}

*300: BKV DNA weakly positive below the limit of quantification 
worse renal function [1,19-24]. Thus, a second, organ-specific hit, such as donor-recipient human leukocyte antigen mismatch, appeared to be necessary for the final development of BK viremia and/or nephropathy [24]. A missing second hit and an adequate humoral immune response [25] in our four BK positive patients may have contributed to avoidance of high level BK viremia and presumptive or manifest BK-PyVAN.

\section{Conclusions}

In conclusion, BKV viremia in critically ill surgical haemorrhagic and septic shock patients appears to be rare and associated with low BK viremia, only. Thus, it is very unlikely that BKV viremia results in nephropathy later on in these patients.

\section{Author details \\ 'Department of Anaesthesiology, University Hospital UIm, Steinhoevelstr. 9, 89075 Ulm, Germany. ${ }^{2}$ Institute of Virology and Immunobiology, University Wuerzburg, Versbacher Str.7, 97078 Wuerzburg, Germany. ${ }^{3}$ Department of Experimental Anaesthesiology, University Hospital Medical School UIm, Steinhoevelstr. 9, 89075 Ulm, Germany.}

\section{Authors' contributions}

MN, BW, EMS and MW participated in study conception, study design, data analysis, interpretation and drafting of the manuscript. $\mathrm{MN}, \mathrm{MH}$ and $\mathrm{MW}$ participated in collection of blood samples and data acquisition. MN and BW performed the detection of BKV DNA via real-time polymerase chain reaction (rt-PCR). All authors read and approved the final manuscript.

\section{Competing interests}

The authors declare that they have no competing interests.

Received: 27 January 2012 Accepted: 16 February 2012 Published: 16 February 2012

\section{References}

1. Puliyanda DP, Amet N, Dhawan A, Hilo L, Radha RK, Bunnapradist S, Czer L, Martin P, Jordan S, Toyoda M: Isolated heart and liver transplant recipients are at low risk for polyomavirus BKV nephropathy. Clin Transplant 2006, 20(3):289-294.

2. Hariharan S: BK virus nephritis after renal transplantation. Kidney Int 2006, 69(4):655-662.

3. Ling PD, Lednicky JA, Keitel WA, Poston DG, White ZS, Peng R, Liu Z, Mehta SK, Pierson DL, Rooney CM, et al: The dynamics of herpesvirus and polyomavirus reactivation and shedding in healthy adults: a 14-month longitudinal study. J Infect Dis 2003, 187(10):1571-1580.

4. Kaneko T, Moriyama T, Tsubakihara Y, Horio M, Imai E: Prevalence of human polyoma virus (BK virus and $J C$ virus) infection in patients with chronic renal disease. Clin Exp Nephrol 2005, 9(2):132-137.

5. Heininger A, Jahn G, Engel C, Notheisen T, Unertl K, Hamprecht K: Human cytomegalovirus infections in nonimmunosuppressed critically ill patients. Crit Care Med 2001, 29(3):541-547.

6. von Muller L, Klemm A, Weiss M, Schneider M, Suger-Wiedeck H, Durmus N, Hampl W, Mertens T: Active cytomegalovirus infection in patients with septic shock. Emerg Infect Dis 2006, 12(10):1517-1522.

7. Luyt CE, Combes A, Deback C, Aubriot-Lorton MH, Nieszkowska A, Trouillet JL, Capron F, Agut H, Gibert C, Chastre J: Herpes simplex virus lung infection in patients undergoing prolonged mechanical ventilation. Am J Respir Crit Care Med 2007, 175(9):935-942.

8. Limaye AP, Kirby KA, Rubenfeld GD, Leisenring WM, Bulger EM, Neff MJ, Gibran NS, Huang ML, Santo Hayes TK, Corey L, et al: Cytomegalovirus reactivation in critically ill immunocompetent patients. JAMA 2008, 300(4):413-422.
9. Levy MM, Fink MP, Marshall JC, Abraham E, Angus D, Cook D, Cohen J, Opal SM, Vincent JL, Ramsay G: 2001 SCCM/ESICM/ACCP/ATS/SIS International Sepsis Definitions Conference. Intensive Care Med 2003, 29(4):530-538.

10. Mehta RL, Kellum JA, Shah SV, Molitoris BA, Ronco C, Warnock DG, Levin A: Acute Kidney Injury Network: report of an initiative to improve outcomes in acute kidney injury. Crit Care 2007, 11(2):R31.

11. Vincent JL, de Mendonca A, Cantraine F, Moreno R, Takala J, Suter PM, Sprung $\mathrm{CL}$, Colardyn F, Blecher S: Use of the SOFA score to assess the incidence of organ dysfunction/failure in intensive care units: results of a multicenter, prospective study. Working group on "sepsis-related problems" of the European Society of Intensive Care Medicine. Crit Care Med 1998, 26(11):1793-1800.

12. Moreno RP, Metnitz PG, Almeida E, Jordan B, Bauer P, Campos RA, lapichino G, Edbrooke D, Capuzzo M, Le Gall JR: SAPS 3-From evaluation of the patient to evaluation of the intensive care unit. Part 2: Development of a prognostic model for hospital mortality at ICU admission. Intensive Care Med 2005, 31(10):1345-1355.

13. Knaus WA, Draper EA, Wagner DP, Zimmerman JE: APACHE II: a severity of disease classification system. Crit Care Med 1985, 13(10):818-829.

14. Hirsch $H H$, Mohaupt M, Klimkait T: Prospective monitoring of BK virus load after discontinuing sirolimus treatment in a renal transplant patient with BK virus nephropathy. J Infect Dis 2001, 184(11):1494-1495.

15. Brennan DC, Agha I, Bohl DL, Schnitzler MA, Hardinger KL, Lockwood M, Torrence S, Schuessler R, Roby T, Gaudreault-Keener M, et al: Incidence of BK with tacrolimus versus cyclosporine and impact of preemptive immunosuppression reduction. Am J Transplant 2005, 5(3):582-594.

16. Hirsch HH, Knowles W, Dickenmann M, Passweg J, Klimkait T, Mihatsch MJ, Steiger J: Prospective study of polyomavirus type BK replication and nephropathy in renal-transplant recipients. N Engl J Med 2002, 347(7):488-496.

17. Hurault de Ligny B, Francois A, Lobbedez T, Comoz F, Etienne I, E Haggan W, Pujo M, Godin M, Ryckelynck JP: Clinical aspects of human polyomaviruses in renal transplantation. Presse Med 2003, 32(14):659-666

18. Hirsch HH, Brennan DC, Drachenberg CB, Ginevri F, Gordon J, Limaye AP, Mihatsch MJ, Nickeleit V, Ramos E, Randhawa P, et al: Polyomavirusassociated nephropathy in renal transplantation: interdisciplinary analyses and recommendations. Transplantation 2005, 79(10):1277-1286.

19. Barton TD, Blumberg EA, Doyle A, Ahya VN, Ferrenberg JM, Brozena SC, Limaye AP: A prospective cross-sectional study of BK virus infection in non-renal solid organ transplant recipients with chronic renal dysfunction. Transpl Infect Dis 2006, 8(2):102-107.

20. Thomas LD, Vilchez RA, White ZS, Zanwar P, Milstone AP, Butel JS, Dummer S: A prospective longitudinal study of polyomavirus shedding in lung-transplant recipients. J Infect Dis 2007, 195(3):442-449.

21. Salama M, Boudville N, Speers D, Jeffrey GP, Ferrari P: Decline in native kidney function in liver transplant recipients is not associated with BK virus infection. Liver Transp/ 2008, 14(12):1787-1792.

22. Doucette KE, Pang $\mathrm{XL}$, Jackson $\mathrm{K}$, Burton I, Carbonneau M, Cockfield $\mathrm{S}$, Preiksaitis JK: Prospective monitoring of BK polyomavirus infection early posttransplantation in nonrenal solid organ transplant recipients. Transplantation 2008, 85(12):1733-1736.

23. Loeches B, Valerio M, Perez M, Banares R, Ledesma J, Fogeda M, Salcedo M, Rincon D, Bouza E, Munoz P: BK virus in liver transplant recipients: a prospective study. Transplantation Proc 2009, 41(3):1033-1037.

24. Pendse SS, Vadivel N, Ramos E, Mudge GH, Von Visger T, Fang JC, Chandraker A: BK viral reactivation in cardiac transplant patients: evidence for a double-hit hypothesis. J Heart Lung Transplant 2006, 25(7):814-819.

25. Hariharan S, Cohen EP, Vasudev B, Orentas R, Viscidi RP, Kakela J, DuChateau B: BK virus-specific antibodies and BKV DNA in renal transplant recipients with BKV nephritis. Am J Transplant 2005, 5(11):2719-2724.

doi:10.1186/1756-0500-5-100

Cite this article as: Nass et al.: BK viremia in critically ill surgical patients with hemorrhagic or septic shock. BMC Research Notes 2012 5:100. 